\title{
Article
}

Mycosphere

\section{Fungi from Asian Karst formations II. Two new species of Occultibambusa (Occultibambusaceae, Dothideomycetes) from karst landforms of China}

\author{
Zhang JF ${ }^{1,2,3}$, Liu JK ${ }^{2,4}$, Hyde $\mathrm{KD}^{2,3}$, Yang $\mathrm{W}^{1} \&$ Liu $\mathrm{ZY}^{2 *}$ \\ ${ }^{I}$ Guizhou Tea Research Institute, Guizhou Academy of Agricultural Sciences, Guiyang 550006, P. R. China. \\ ${ }^{2}$ Guizhou Key Laboratory of Agricultural Biotechnology, Guizhou Academy of Agricultural Sciences, Guiyang 550006, \\ P. R. China \\ ${ }^{3}$ Center of Excellence in Fungal Research, Mae Fah Luang University, Chiang Rai 57100, Thailand. \\ ${ }^{4}$ Guizhou Institute of Biotechnology, Guiyang, Guizhou 550006, P. R. China
}

Zhang JF, Liu JK, Hyde KD, Yang W, Liu ZY 2017 - Fungi from Asian Karst formations II. Two new species of Occultibambusa (Occultibambusaceae, Dothideomycetes) from karst landforms of China. Mycosphere 8(4), 550-559, Doi 10.5943/mycosphere/8/4/4

\begin{abstract}
During an investigation of saprobic ascomycetes from karst landforms in southwest China, two new species were isolated from dead bamboo culms collected from Maolan Town in Guizhou Province. The new taxa share similar morphological characters as known Occultibambusa species in having immersed, papillate ascomata, broadly-cylindrical to clavate asci and fusiform, hyaline to brown ascospores. Phylogenetic analysis of combined LSU, SSU, TEF1- $\alpha$ and RPB2 sequence data also placed the new taxa within the genus Occultibambusa in the family Occultibambusaceae with good support. The new taxa can be distinguished from other species by septation and different-sized ascospores and the present or absence of sheaths. The new species, Occultibambusa jonesii and $O$. maolanensis are introduced here, with descriptions, illustrations and molecular data.
\end{abstract}

Key words - Dothideomycetes - phylogeny -Pleosporales - taxonomy

\section{Introduction}

We are carrying out the fungal diversity survey in the Karst formations of the Asian region and this is the second in a series of papers (Chen et al. 2017). The family of Occultibambusaceae D.Q. Dai \& K.D. Hyde was introduced by Dai et al. (2017) and assigned to the order Pleosporales. The family is typified by Occultibambusa and characterized by immersed, solitary to gregarious ascomata, cylindrical to clavate, bitunicate asci and fusiform, hyaline to brown, septate ascospores and rather diverse asexual morphs. The family presently comprises four genera: Neooccultibambusa Doilom \& K.D. Hyde (Doilom et al. 2017), Occultibambusa D.Q. Dai, Seriascoma Phookamsak., D.Q. Dai \& K.D. Hyde (Dai et al. 2017) and Versicolorisporium Sat. Hatak., Kaz. Tanaka \& Y. Harada (Hatakeyama et al. 2008).

Species in this family occur on monocotyledons and hardwood trees, and share similar morphology with species of the genera Bambusicola, Lophiostoma and Massarina in having clavate asci and fusiform ascospores, however they can be distinguished readily via phylogenetic analysis 
(Zhang et al. 2009, Dai et al. 2012, 2015, 2017). Dai et al. (2017) indicated that the family Occultibambusaceae is phylogenetically close to Biatriosporaceae, but differs from members of the latter, which usually having dark brown ascospores with hyaline, rounded, swollen ends which release mucilage (Hyde et al. 1986, 2013, Dai et al. 2017). There is confusion surrounding Biatriosporaceae and until Biatriospora marina is epitypified (sensu Ariyawansa et al. 2014), we follow the classification of Wijayawardene et al. (2014).

In the course of an ongoing survey of saprobic ascomycetes from Karst landforms, two new taxa were isolated from dead bamboo culms collected in Guizhou Province, southwest China. Molecular analysis of combined LSU, SSU, TEF1- $\alpha$ and RPB2 sequence data placed the new taxa within the family of Occultibambusaceae where they cluster with Occultibambusa species with good support. The taxa also share similar morphological characters with existing Occultibambusa species. Therefore, $O$. jonesii and $O$. maolanensis are introduced to accommodate the new taxa.

\section{Materials \& Methods}

\section{Collection, examination and isolation of specimens}

Samples were collected from Maolan Town in Guizhou Province, and taken back to laboratory in envelopes. Examination and vertical sections of samples were processed under a stereomicroscope (Nikon SMZ 745) and a compound microscope (Nikon E100). Micromorphological characters were observed under the Nikon ECLIPSE Ni compound microscope and captured by using the Cannon EOS 70D digital camera with DIC microscopy. The Tarosoft (R) Image Frame Work version 0.9.7 program was used to measure micro-morphological characters, and photographic plates were edit by using Adobe Photoshop CS6 (Adobe Systems Inc., USA).

Isolates were made from single ascospore following the method by Chomnunti et al. (2014). The single germinated ascospore was individually transferred to potato dextrose agar (PDA; $39 \mathrm{~g} / \mathrm{l}$ distilled water, Difco potato dextrose) and incubated at $25{ }^{\circ} \mathrm{C}$ in the dark for recording growth rates and culture characters. The holotypes are deposited at the herbarium of Guizhou Academy of Agricultural Sciences (GZAAS), Guiyang, China and duplicated at the herbarium of Kunming Institute of Botany, Chinese Academy of Sciences (HKAS), Kunming, China. Isolates are deposited at Guizhou Culture Collection (GZCC), Gui Yang, China and duplicated at Kunming Culture Collection (KUMCC), Kunming, China. Facesoffungi and Index Fungorum numbers are provided as explained in Jayasiri et al. (2015) and Index Fungorum (2017).

\section{DNA extraction, PCR amplification and sequencing}

Genomic DNA was extracted from the fresh mycelia, and the Ezup Column Fungi Genomic DNA Purification Kit (Sangon Biotech, Shanghai, P. R. China) was used to processed it following the manufacturer's instructions.

Primers of LR0R and LR5 (Vilgalys \& Hester 1990), NS1 and NS4 (White et al. 1990) were used for the amplification of large subunit rDNA (LSU) and small subunit rDNA (SSU) respectively. Translation elongation factor 1- $\alpha$ gene (TEF 1- $\alpha$ ) and RNA polymerase II second largest subunit gene (RPB2) were amplified by the primers of EF1-983F and EF1-2218R (Rehner 2001), fRPB2-5f and fRPB2-7cr (Liu et al. 1999) respectively.

DNA amplification procedure was performed by Polymerase Chain Reaction (PCR) in a 50 $\mu \mathrm{l}$ reaction volume, which contains $19 \mu \mathrm{l}$ Distilled-Deionized-water, $25 \mu \mathrm{l}$ of $2 \times$ Power Taq PCR Master Mix (TIANGEN Co., China), $2 \mu$ of DNA template and $2 \mu \mathrm{l}$ of each forward and reverse primers. The PCR thermal cycle program of LSU, SSU and TEF1- $\alpha$ gene amplifications were provided as: initially $94{ }^{\circ} \mathrm{C}$ for 3 minutes, followed by 40 cycles of denaturation at $94{ }^{\circ} \mathrm{C}$ for 45 seconds, annealing at $56^{\circ} \mathrm{C}$ for 50 seconds, elongation at $72{ }^{\circ} \mathrm{C}$ for 1 minute, and a final extension at $72{ }^{\circ} \mathrm{C}$ for 10 minutes. The PCR thermal cycle program for RPB2 genes was provided as: initially 95 ${ }^{\circ} \mathrm{C}$ for 5 minutes, followed by 40 cycles of denaturation at $95{ }^{\circ} \mathrm{C}$ for 1 minute, annealing at $52{ }^{\circ} \mathrm{C}$ for 2 minutes, elongation at $72{ }^{\circ} \mathrm{C}$ for 90 seconds, and a final extension at $72{ }^{\circ} \mathrm{C}$ for 10 minutes. The quality of PCR products was checked by using $1.2 \%$ agarose gel electrophoresis stained with 
ethidium bromide and then sent to sequence at Invitrogen Biotechnology Co., Ltd (Shanghai, P. R. China). Newly generated sequences have been submitted to GenBank.

\section{Sequence alignment and phylogenetic analyses}

Newly generated sequences were checked and combined in the program of BioEdit v.7.1.3 (Hall 1999). Then, a BLAST search with the LSU sequence in GenBank was performed to reveal the preliminary identification, and additional sequences were downloaded based on their identities and related publications. Single gene sequence alignments were processed in MAFFT v. 7.215 (Katoh \& Standley 2013: http://mafft.cbrc.jp/alignment/server/index.html) respectively and edited manually where necessary to minimize the number of uninformative gaps in BioEdit v.7.2. The program of MEGA v.6.6 (Tamura et al. 2013) was used to concatenate the individual datasets into a combined dataset. And the data were converted from fasta to nexus format for Bayesian analysis in ClustalX2 v.1.83 (Thompson et al. 1997) or PHYLIP format for RAxML analysis in the online program ALTER (http://sing.ei.uvigo.es/ALTER/).

Maximum likelihood (ML) analysis with 1000 bootstrap replicates was run in the RAxMLGUI v. 1.5b1 program (Silvestro \& Michalak, 2012), and the default algorithm was used from a random starting tree for each replicate. The number of replications was inferred using the stopping criterion. Branches of bootstrap values greater than $75 \%$ were shown in the tree. The final tree was selected among suboptimal trees from each replicate by comparing likelihood scores under the GTR+GAMMA substitution model.

Bayesian analysis was performed by using MrBayes v. 3.0b4 (Huelsenbeck \& Ronquist 2001). The best-fit model of evolution was estimated in MrModeltest 2.3 (Nylander 2004). Posterior probabilities (PP) (Rannala \& Yang 1996, Zhaxybayeva \& Gogarten 2002) were determined by Markov Chain Monte Carlo sampling (MCMC) in MrBayes v. 3.0b4. Six simultaneous Markov chains were run for 1000000 generations and trees were sampled every 100th generation (resulting in 10000 total trees). The first 2000 trees, representing the burn-in phase of the analyses, were discarded and the remaining 8000 trees used for calculating posterior probabilities (PP) in the majority rule consensus tree. The branches, which posterior probabilities with those equal or greater than 0.95 , were thickened in Fig. 1.

The final layout of phylogenetic tree was visualized with TreeView v. 1.6.6 (Page 1996), and edit by using Adobe Illustrator CS5 (Adobe Systems Inc., USA).

\section{Results}

\section{Phylogenetic analysis}

The LSU, SSU, TEF1- $\alpha$ and RPB2 dataset was combined and comprised 25 taxa with Westerdykella ornata (CBS 379.55) as the outgroup taxon. The dataset comprised 3,677 characters (LSU-851, SSU-982, TEF1- $\alpha-919$, RPB2-916) after alignment, of which 2,866 characters are constant, and 644 characters are parsimony-informative, while 167 variable characters are parsimony-uninformative in the maximum parsimony (MP) analysis. The best scoring RAxML tree is shown in Fig. 1. The optimal tree (not shown) generated by Bayesian analysis had a similar topology with the RAxML tree.

Most of sequence data for this study are selected from Dai et al. (2017) and Hyde et al. (2016), and most of other families, which are phylogenetically close to this group, are selected from previous studies (Hyde et al. 2013, Liu et al. 2014). The results show that the two new taxa are placed in the genus Occultibambusa. Occultibambusa jonesii is phylogenetically close to $O$. aquatica with high support (MLBS 97/ BIPP 1.0), and O. maolanensis clusters with O. fusispora with good support (MLBS 85/ BIPP 0.99). Moreover, all Occultibambusa species formed a well-supported (MLBS 83/ BIPP 1.0) clade in the family of Occultibambusaceae. 
Table 1 GenBank accession numbers of sequences used in phylogenetic analyses. New sequences from this study are in bold.

\begin{tabular}{|c|c|c|c|c|c|}
\hline \multirow[t]{2}{*}{ Species name } & \multirow[t]{2}{*}{ Strain No. } & \multicolumn{4}{|c|}{ GenBank accession number } \\
\hline & & $\overline{\mathbf{L S U}}$ & SSU & TEF1- $\alpha$ & RPB2 \\
\hline Biatriospora mackinnonii & CBS 674.75 & KF015612 & GQ387552 & KF407986 & KF015703 \\
\hline Biatriospora marina & CY 1228 & GQ925848 & GQ925835 & GU479848 & GU479823 \\
\hline Biatriospora sp. & CCF 4485 & LN626683 & LN626677 & LN626671 & LN626663 \\
\hline Dendryphion europaeum & CPC 22943 & KG869203 & --- & --- & --- \\
\hline $\begin{array}{l}\text { Neooccultibambusa } \\
\text { chiangraiensis }\end{array}$ & $\begin{array}{l}\text { MFLUCC 12- } \\
0559\end{array}$ & KU764699 & KU712458 & --- & --- \\
\hline Neooccultibambusa sp. & $\begin{array}{l}\text { MFLUCC 12- } \\
0564\end{array}$ & --- & --- & KU872761 & --- \\
\hline Neoroussoella bambusae & $\begin{array}{l}\text { MFLUCC 11- } \\
0124\end{array}$ & KJ474839 & --- & KJ474848 & KJ474856 \\
\hline Occultibambusa aquatica & $\begin{array}{l}\text { MFLUCC 11- } \\
0006\end{array}$ & KX698110 & KX698112 & --- & --- \\
\hline Occultibambusa bambusae & $\begin{array}{l}\text { MFLUCC 11- } \\
0394\end{array}$ & KU863113 & KU872117 & KU940194 & KU940171 \\
\hline Occultibambusa bambusae & $\begin{array}{l}\text { MFLUCC 13- } \\
0855\end{array}$ & KU863112 & KU872116 & KU940193 & KU940170 \\
\hline Occultibambusa fusispora & $\begin{array}{l}\text { MFLUCC 11- } \\
0127\end{array}$ & KU863114 & --- & KU940195 & KU940172 \\
\hline Occultibambusa jonesii & $\begin{array}{l}\text { GZCC 16- } \\
0117\end{array}$ & KY628322 & KY628324 & KY814756 & KY814758 \\
\hline Occultibambusa maolanensis & $\begin{array}{l}\text { GZCC 16- } \\
0116\end{array}$ & KY628323 & KY628325 & KY814757 & KY814759 \\
\hline Occltibambusa pustulata & $\begin{array}{l}\text { MFLUCC 11- } \\
0502\end{array}$ & KU863115 & KU872118 & --- & --- \\
\hline $\begin{array}{l}\text { Paradictyoarthrinium } \\
\text { diffractum }\end{array}$ & $\begin{array}{l}\text { MFLUCC 13- } \\
0466\end{array}$ & KP744498 & KP753960 & --- & --- \\
\hline $\begin{array}{l}\text { Paradictyoarthrinium } \\
\text { tectonicola }\end{array}$ & $\begin{array}{l}\text { MFLUCC 13- } \\
0465\end{array}$ & KP744500 & KP753961 & --- & --- \\
\hline Roussoella hysterioides & HН 26988 & AB524622 & AB524481 & AB539115 & AB539102 \\
\hline Roussoella nitidula & $\begin{array}{l}\text { MFLUCC 11- } \\
0182\end{array}$ & KJ474843 & --- & KJ474852 & KJ474859 \\
\hline Roussoella nitidula & $\begin{array}{l}\text { MFLUCC 11- } \\
0634\end{array}$ & KJ474842 & --- & KJ474851 & KJ474858 \\
\hline Roussoella pustulans & KT 1709 & AB524623 & AB524482 & AB539116 & AB539103 \\
\hline Seriascoma didymospora & $\begin{array}{l}\text { MFLUCC 11- } \\
0179\end{array}$ & KU863116 & --- & KU940196 & KU940173 \\
\hline Seriascoma didymospora & $\begin{array}{l}\text { MFLUCC 11- } \\
0194\end{array}$ & KU863117 & --- & KU940197 & KU940174 \\
\hline Torula herbarum & CBS 111855 & KF443386 & KF443391 & KF443403 & KF443396 \\
\hline Torula hollandica & CBS 220.69 & KF443384 & --- & --- & --- \\
\hline Westerdykella ornata & CBS 379.55 & GU301880 & GU296208 & GU349021 & GU371803 \\
\hline
\end{tabular}

Abbreviation: CBS: Centraalbureau voor Schimmelcultures, The Netherlands; CPC: Collection of Pedro Crous housed at CBS; GZCC: Guizhou culture collection, Guizhou, China; MFLUCC: Mae Fah Luang University Culture Collection, Chiang Rai, Thailand; KT: K. Tanaka.

\section{Taxonomy}

Occultibambusa jonesii J.F. Zhang, J.K. Liu, K.D. Hyde \& Z.Y. Liu, sp. nov. Fig. 2 Index Fungorum number: IF 552743

Faces of fungi number: FoF 02873

Etymology - Named in honour of E.B. Gareth Jones for his contributions to tropical mycology. Holotype - GZAAS 16-0162 
Saprobic on dead bamboo culms, forming dark, raised spots on the host surface. Sexual morph Ascostromata 196-236 $\mu \mathrm{m}$ high, 200-260 $\mu \mathrm{m}$ diam, immersed to erumpent, solitary to gregarious, subglobose, ostiolate, papillate, coriaceous, flattened at the base. Peridium up to 10-52

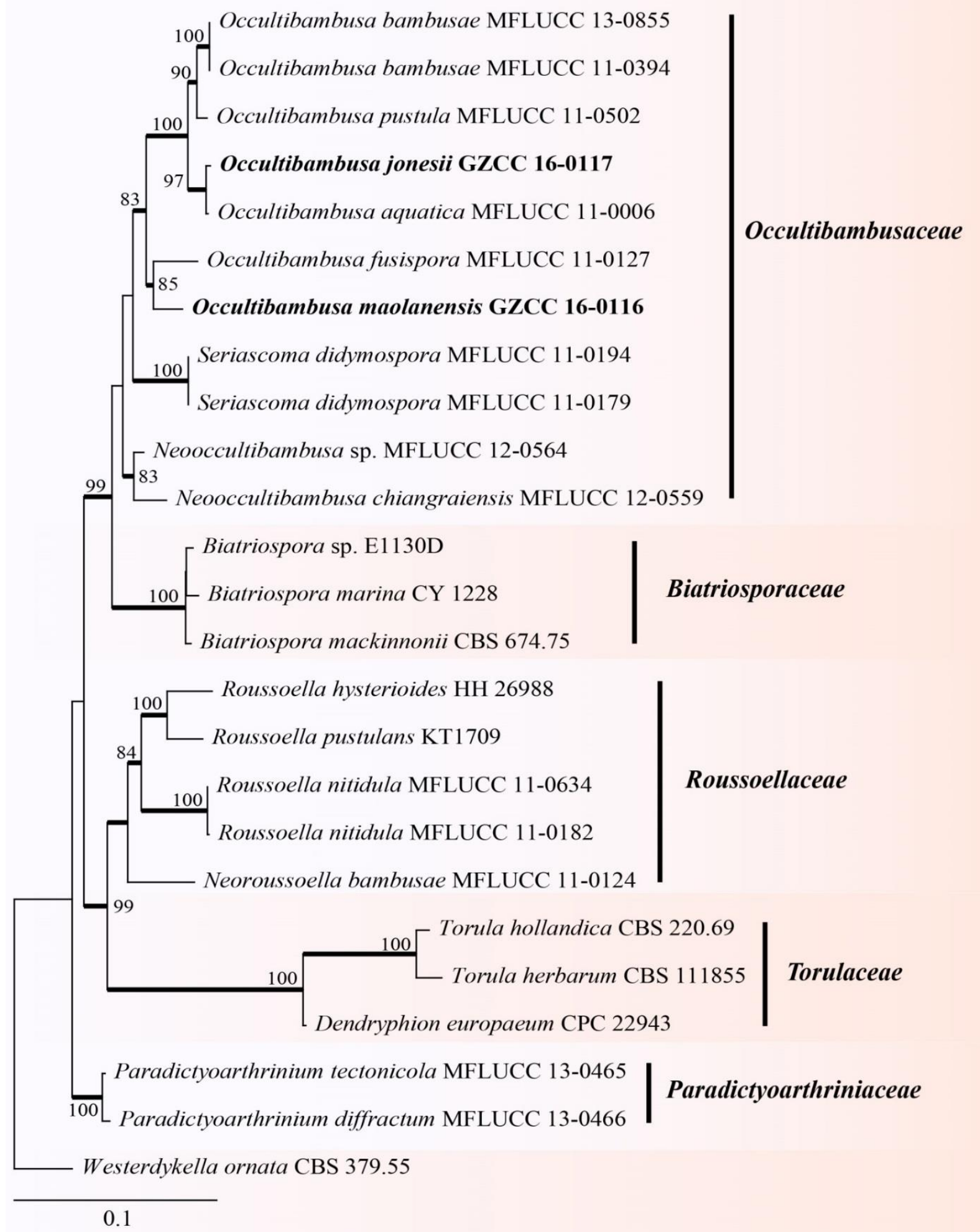

Fig. 1 - Maximum likelihood phylogenetic tree by RAxML (GTR+G model) analysis based on combined LSU, SSU, TEF1- $\alpha$ and RPB2 sequence data. ML values ( $\geq 75 \%)$ resulting from 1000 bootstrap replicates are shown near the nodes and branches with Bayesian posterior probabilities (PP) greater than 0.95 are in bold. The original isolate numbers are noted after the species names. The tree is rooted to Westerdykella ornata (CBS 379.55), and the scale bar shows 0.1 changes. 

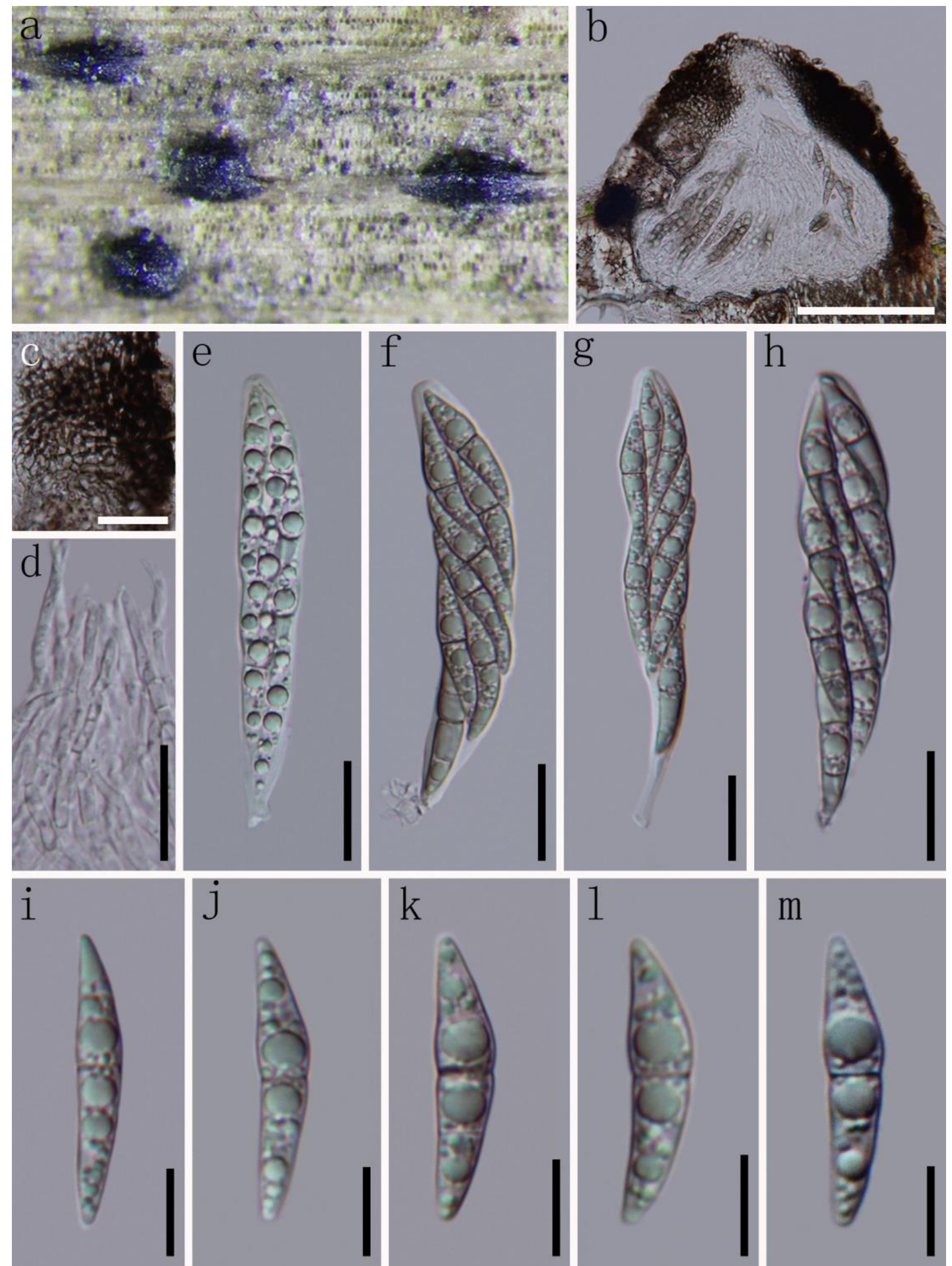

Fig. 2 - Occultibambusa jonesii (holotype, GZAAS 16-0162). a Appearance of ascostromata on dead bamboo culms. b Vertical section through ascostroma. c Section through peridium. d Pseudoparaphyses. e-h Asci with ascospores. i-m Ascospores. Scale bars: $b=100 \mu \mathrm{m}, \mathrm{c}=30 \mu \mathrm{m}, \mathrm{d}-$ $\mathrm{h}=20 \mu \mathrm{m}, \mathrm{i}-\mathrm{m}=10 \mu \mathrm{m}$ 
$\mu \mathrm{m}$ wide, thin at the base and becoming wider laterally, composed of several layers of dark brown cells, arranged in a textura angularis, and the outermost layer intermingled with host tissue. Hamathecium comprising dense, 2-3 $\mu \mathrm{m}$ wide, pseudoparaphyses, which anastomose above and between the asci, embedded in a gelatinous matrix. Asci $(65-) 75-89(-105) \times 13.5-19 \mu \mathrm{m}(\bar{x}=85 \times$ $16.5 \mu \mathrm{m}, \mathrm{n}=20), 8$-spored, bitunicate, fissitunicate, broadly cylindrical to clavate, short pedicellate, apically rounded to truncate, with an ocular chamber. Ascospores $27-33.5 \times 5.5-6.5 \mu \mathrm{m}(\bar{x}=29.5 \times$ $6 \mu \mathrm{m}, \mathrm{n}=20$ ), 1-3-seriate, 2-celled, constricted at the septum, and the upper cell swollen near the septum, inequilateral-fusiform, slightly curved, hyaline and guttulate when young and becoming brown to grayish when mature, wall smooth, without any mucilaginous sheath and appendages. Asexual morph - Undetermined.

Culture characters - Ascospores geminating on WA within 12 hours. Colonies reaching $35 \mathrm{~mm}$ diameter on PDA in three weeks at $25 \mathrm{C}$, circular, dense, regular at the margin, raised at the center, gray from above and dark olive-green to black from below.

Material examined - CHINA, Guizhou Province, Maolan Town, on dead bamboo culms, 20 July 2016, J.F. Zhang, MLC'-12, (GZAAS 16-0162, holotype); ex-type living culture, GZCC 160117; Ibid., 10 November 2016, J.F Zhang (HKAS96379); living culture KUMCC 17-0136.

Occultibambusa maolanensis J.F. Zhang, J.K. Liu, K.D. Hyde \& Z.Y. Liu, sp. nov.

Fig. 3 Index Fungorum number: IF 552744

Faces of fungi number: FoF 02874

Etymology - Refers to the holotype was collected from Maolan Town.

Holotype - GZAAS 16-0161

Saprobic on dead bamboo culms, forming dark, rounded spots on the host surface. Sexual morph - Ascostromata 544-600 $\mu \mathrm{m}$ diameter, solitary to gregarious, immersed under the epidermis, subglobose, coriaceous, slightly conical in vertical section, and flattened at the base, ostiolate, with a short, rounded, shiny, black papilla. Peridium up to 20-42 $\mu$ m laterally composed of several layers of brown cells, becoming thin-walled and hyaline towards the centrum, arranged in a textura angularis, thick and darkly pigmented around ostiole, intermingled with host tissue. Hamathecium comprising dense, 1.5-2.4 $\mu \mathrm{m}$ wide, hypha-like pseudoparaphyses, branched and swollen towards the terminal cells, anastomosing above and between the asci, embedded in a gelatinous matrix. Asci $(66-) 77-85(-94) \times 17-20(-24) \mu \mathrm{m}(\bar{x}=81 \times 20 \mu \mathrm{m}, \mathrm{n}=20), 8$-spored, bitunicate, fissitunicate, broadly cylindrical to clavate, short pedicellate, apically rounded to truncated with a visible ocular chamber (2.5-3.5 $\mu \mathrm{m}$ wide). Ascospores 25-31 $\times 8-10 \mu \mathrm{m}(\bar{x}=28 \times 9 \mu \mathrm{m}, \mathrm{n}=30), 2-4$-seriate, 2 celled, and moderately constricted at the septum, inequality-fusiform, apical cells $14-18 \mu \mathrm{m}$, basal cells 11-15 $\mu \mathrm{m}$, slightly curved, hyaline and guttulate when young and become light brown when mature, wall smooth, without any mucilaginous sheath and appendages. Asexual morph Undetermined.

Culture characters - Ascospores geminating on WA within 24 hours. Colonies reaching $30 \mathrm{~mm}$ diameter on PDA in three weeks at $25^{\circ} \mathrm{C}$, circular, dense, regular at the margin, gray from above and black from below.

Specimens examined - CHINA, Guizhou Province, Maolan Town, on dead bamboo culms, 8 July 2015, J.F. Zhang, MLC-29, (GZAAS 16-0161, holotype); ex-type living culture, GZCC 160116; Ibid., 10 November 2016, J.F Zhang (HKAS96380); living culture KUMCC 17-0137.

\section{Discussion}

The taxa that occur on bamboo are rather unique, often family specific grouping that appear to have a considerable diversity (Hyde et al. 2002, Liu et al. 2011, Jaklitsch et al. 2015, Dai et al. 2017). In this paper, we introduce two new species, Occultibambusa jonesii and O. maolanensis from bamboo, with molecular and morphological support. Occultibambusa jonesii is phylogenetically close to $O$. aquatica, but can be distinguished from it by its larger asci $(65-105 \times 13.5-19 \mu \mathrm{m}$ vs. 73-86 $\times 9-13 \mu \mathrm{m})$, longer ascospores $(27-33.5 \mu \mathrm{m}$ vs. 19-25 $\mu \mathrm{m})$, and the new taxa also lacks a mucilage sheath surrounding the ascospores. Occultibambusa maolanensis clusters 

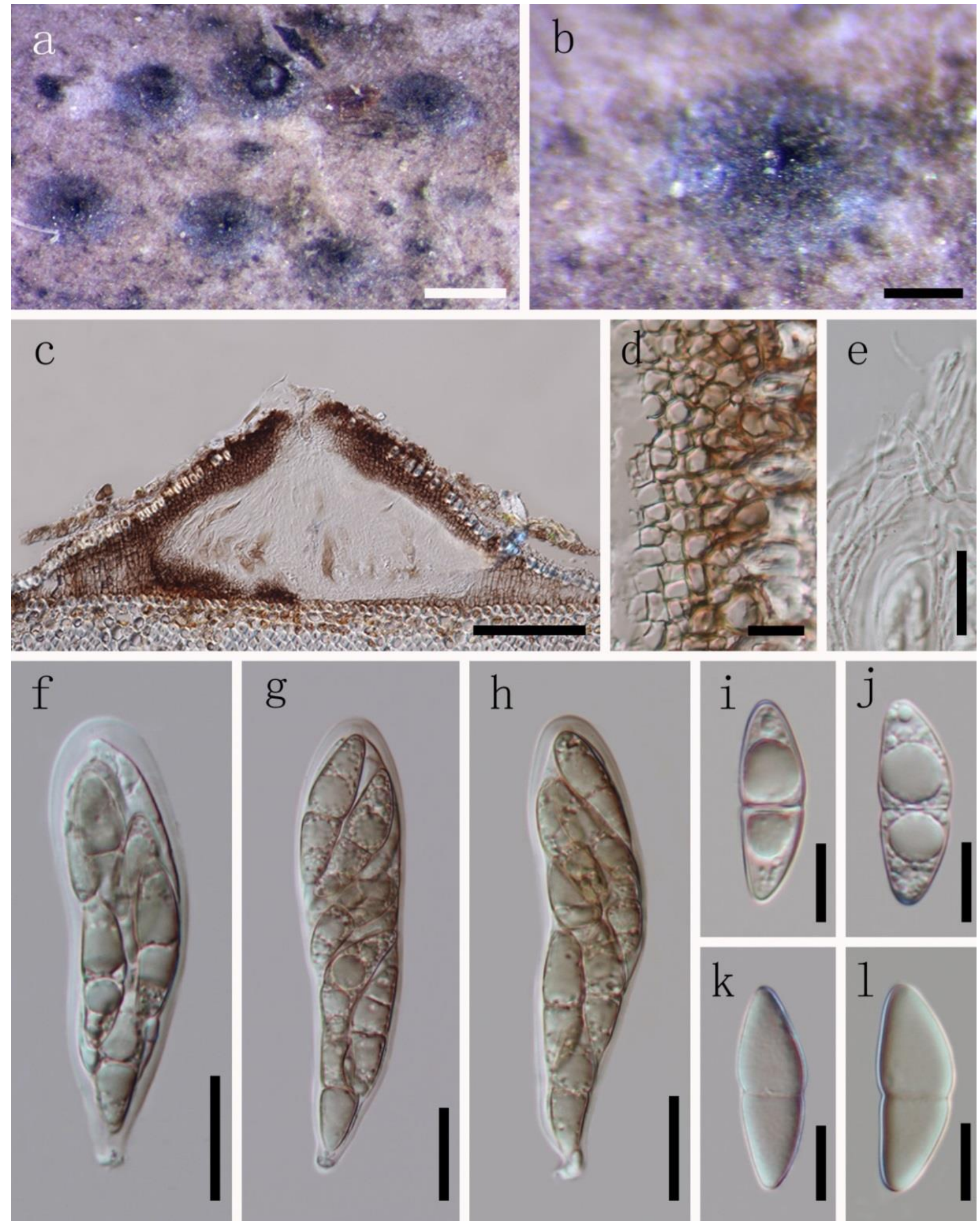

Fig. 3 - Occultibambusa maolanensis (holotype, GZAAS 16-0161). a Appearance of ascostromata on dead bamboo culms. b Rounded, shiny black papilla. c Vertical section through ascostroma. d Section through peridium. e Pseudoparaphyses. f-h Asci with ascospores. i-l Ascospores. Scale bars: $\mathrm{a}=500 \mu \mathrm{m}, \mathrm{b}=200 \mu \mathrm{m}, \mathrm{c}=100 \mu \mathrm{m}, \mathrm{d}=10 \mu \mathrm{m}, \mathrm{e}-\mathrm{n}=20 \mu \mathrm{m}$

with $O$. fusispora in a well-supported clade in the phylogenetic analysis, but they can be distinguished readily by the difference in appearance of ascostromata, the wider asci (17-24 $\mu \mathrm{m}$ vs. 11-16 $\mu \mathrm{m})$ and larger ascospores $(25-31 \times 8-10 \mu \mathrm{m}$ vs. 20-26 × 5-6.5 $\mu \mathrm{m})$. Both species have 
pseudoparaphyses embedded in a gelatinous matrix and anastomose between and above the asci and are more like trabeculae in Occultibambusa maolanensis, but typical of cellular pseudoparaphyses in $O$. jonesii. Liew et al. (2000) show that the nature of pseudoparaphyses had little relevance above the family level, while in this study different types of pseudoparaphyses are found even in the same genus (Figs 2d, 3e).

The family of Occultibambusaceae includes four genera: Neooccultibambusa, Occultibambusa, Seriascoma and Versicolorisporium, however, the phylogenetic placement of Versicolorisporium is not well-resolved. Its placement is not stable and when used in analyses it affects the molecular placements of genera (results not shown). Therefore, we excluded the molecular data of Versicolorisporium in our phylogenetic analysis. The two new taxa are both morphologically and phylogenetically with described Occultibambusa species, and the lack of Versicolorisporium sequence data has no effect on phylogenetic relationships of species in Occultibambusa.

\section{Acknowledgements}

The Research of Featured Microbial Resources and Diversity Investigation in Southwest Karst area (Project No. 2014FY120100) is gratefully thanked for financial support. We would like to thank Hai-Yan Ran for the molecular work. Jian-Kui Liu would like to thank Science and Technology Foundation of Guizhou Province (LH [2015]7061) and National Natural Science Foundation of China (NSFC 31600032).

\section{References}

Ariyawansa HA, Tanaka K, Thambugala KM, Phookamsak R et al. 2014 - A molecular phylogenetic reappraisal of the Didymosphaeriaceae (= Montagnulaceae). Fungal Diversity 68, 69-104. DOI:10.1007/s13225-014-0305-6

Chen YY, Maharachchikumbura SSN, Liu JK, Hyde KD et al. 2017 - Fungi from Asian Karst formations I. Pestalotiopsis photinicola sp. nov., causing leaf spots of Photinia serrulata. Mycosphere 8, 103-110, Doi 10.5943/mycosphere/8/1/9

Chomnunti P, Hongsanan S, Aguirre-Hudson B, Tian Q et al. 2014 - The sooty moulds. Fungal Diversity 66, 1-36.

Dai DQ, Bahkali AH, Li WJ, Bhat DJ et al. 2015 - Bambusicola loculata sp. nov. (Bambusicolaceae) from bamboo. Phytotaxa 213, 122-130.

Dai DQ, Bhat DJ, Liu JK, Chukeatirote E et al. 2012 - Bambusicola, a new genus from bamboo with asexual and sexual morphs. Cryptogamie Mycologie 33, 363-379.

Dai DQ, Phookamsak R, Wijayawardene NN, Li WJ et al. 2017 - Bambusicolous fungi. Fungal Diversity 82, 1-105. DOI 10.1007/s13225-016-0367-8

Doilom M, Dissanayake AJ, Phillips AJL, Boonmee S et al. 2017 - Microfungi on Tectona grandis (teak) in northern Thailand. Fungal Diversity 82, 107-182. DOI 10.1007/s13225-016-03687

Hall TA 1999 - BioEdit: a user-friendly biological sequence alignment editor and analysis program for Windows 95/98/NT. In Nucleic Acids Symposium Series 41: 95-98.

Hatakeyama S, Tanaka K, Harada Y 2008 - Bambusicolous fungi in Japan (7): a new coelomycetous genus, Versicolorisporium, Mycoscience 49, 211-214.

Huelsenbeck JP, Ronquist F 2001 - MRBAYES: Bayesian inference of phylogenetic trees. Bioinformatics 17, 754-755, available at http://brahms.biology.rochester.edu/software.html

Hyde KD, Zhou DQ, Dalisay, T 2002 - Bambusicolous fungi: A review. Fungal Diversity 9, 1-14.

Hyde KD, Borse BD 1986 - Marine fungi from Seychelles V. Biatriospora marina gen. et sp. nov. from mangrove wood. Mycotaxon 26, 263-270.

Hyde KD, Jones EBG, Liu JK, Ariyawansa H et al. 2013 - Families of Dothideomycetes. Fungal Diversity 63, 1-313.

Hyde KD, Hongsanan S, Jeewon R, Bhat DJ et al. 2016 - Fungal diversity notes 367-491 taxonomic and phylogenetic contributions to fungal taxa. Fungal Diversity 80: 1-270. 
Index Fungorum 2017 -http://www.indexfungorum.org/Names/IndexFungorumRegister.htm (February 2017)

Jaklitsch WM, Fournier J, Dai DQ, Hyde KD, H. Voglmayr H 2015 - Valsaria and the Valsariales. Fungal Diversity 73, 159-202.

Jayasiri SC, Hyde KD, Ariyawansa HA, Bhat DJ et al. 2015 - The Faces of Fungi database: fungal names linked with morphology, phylogeny and human impacts. Fungal Diversity 74, 3-18.

Katoh K, Standley DM 2013 - MAFFT multiple sequence alignment software version 7: improvements in performance and usability. Molecular Biology and Evolution 30:772-780.

Liew ECY, Aptroot A, Hyde, KD 2000 - Phylogenetic significance of the pseudoparaphyses in Loculoascomycete taxonomy. Molecular Phylogenetics and Evolution 16, 392-402.

Liu JK, Phookamsak R, Jones EBG, Zhang Y 2011 - Astrosphaeriella is polyphyletic, with species in Fissuroma gen. nov., and Neoastrosphaeriella gen. nov. Fungal Diversity 51, 135-154.

Liu JK, Phookamsak R, Dai DQ, Tanaka K et al. 2014 - Roussoellaceae, a new pleosporalean family to accommodate the genera Neoroussoella gen. nov., Roussoella and Roussoellopsis. Phytotaxa 181, 1-33.

Liu YJ, Whelen S, Hall BD 1999 - Phylogenetic relationships among ascomycetes: evidence from an RNA polymerse II subunit. Molecular Biology and Evolution 16:1799-1808.

Nylander JAA 2004 - MrModeltest, version 2. Evolutionary Biology Centre, Uppsala University, Uppsala, Sweden.

Page RDM 1996 - TREEVIEW, tree drawing software for Apple Macintosh and Microsoft Windows. Division of Environmental and Evolutionary Biology, Instituteo Biomedical and Life Sciences, University of Glasgow. Glasgow, Scotland, UK.

Rannala B, Yang Z 1996 - Probability distribution of molecular evolutionary trees: a new method of phylogenetic inference. Journal of Molecular Evolution 43, 304-311.

Rehner S 2001 - Primers for elongation factor 1- $\alpha$ (EF1- $\alpha)$, available at http://ocid.NACSE.ORG/research/deephyphae/EFlprimer.pdf

Sivestro D, Michalak I 2012 - raxmlGUI: a graphical front-end for RAxML. Organisms Diversity \& Evolution 12, 335-337.

Tamura K, Peterson D, Peterson N, Stecher G et al. 2011 - MEGA5: molecular evolutionary genetics analysis using maximum likelihood, evolutionary distance, and maximum parsimony methods. Molecular Biology and Evolution 28, 2731-2739.

Thompson JD, Gibson TJ, Plewniak F, Jeanmougin F, Higgins DG 1997 - The CLUSTAL_X windows interface: flexible strategies for multiple sequence alignment aided by quality analysis tools. Nucleic Acids Research 25, 4876-4882.

Vilgalys R, Hester M 1990 - Rapid genetic identification and mapping of enzymatically amplified ribosomal DNA from several Cryptococcus species. Journal of Bacteriology 172, 4238-4246.

White T, Bruns T, Lee S, Taylor J 1990 - Amplification and direct sequencing of fungal ribosomal RNA genes for phylogenetics. In: Innis M, Gelfand D, Shinsky J, White T. (Eds.) PCR protocols: a guide to methods and applications. Academic Press, New York, p, 315-322.

Wijayawardene NN, Crous PW, Kirk PM, Hawksworth DL et al. 2014 - Naming and outline of Dothideomycetes-2014 including proposals for the protection or suppression of generic names. Fungal Diversity 69, 1-55.

Zhang Y, Wang HK, Fournier J, Crous PW et al. 2009 - Towards a phylogenetic clarification of Lophiostoma/Massarina and morphologically similar genera in the Pleosporales. Fungal Diversity 38, 225-251.

Zhaxybayeva O, Gogarten JP 2002 - Bootstrap, Bayesian probability and maximum likelihood mapping: exploring new tools for comparative genome analyses. BMC Genomics 3, 4. 